\title{
A 10-year study of homosexually transmitted infection
}

\author{
J. L. FLUKER \\ Charing Cross Hospital, London
}

\section{Summary}

A 10-year survey is presented of male cases of homosexually acquired infection seen between 1962 and 1971 at Charing Cross Hospital (West London Branch). Tables showing the number of cases of syphilis, gonorrhoea, and other conditions in homosexual and heterosexual males and in females are considered. Tables of other relevant data are also presented. The reasons underlying the changes illustrated, including the Act legalizing homosexual practices between consenting adult males, which became effective in 1968, are discussed.

Certain pathological conditions apparently connected with homosexual practices, such as serum hepatitis, local rectal disease, and mucous colitis, are included and also some relevant manifestations of herpes genitalis and genital warts. Homosexually acquired infection in prisoners is described. Some of the psychiatric effects of homosexuality on clinic patients and also their fears of treatment at clinics are considered, as well as the behavioural differences in response to infection between exclusively homosexuals, bi-sexuals, and married homosexuals.

\section{Introduction}

Homosexuality is as old as the human race but it is only within the last 20 to 25 years that its role in the spread of sexually transmitted infection has been appreciated. Although Harkness (1948) drew attention to the occurrence of rectal manifestations of syphilis, gonorrhoea, and lymphogranuloma venereum, during and immediately after the second world war patients were rarely seen in whom this mode of transmission of infection was unquestioned.

Received for publication January 3, 1976

Presidential Address delivered to the MSSVD on April 25, 1975

Address for reprints: Dr. J. L. Fluker, Martha and Luke Clinic, West London Hospital, Bute Gardens, London W6 7DQ
Personal experience of such patients in the Royal Navy as a medical specialist, and in civilian venereological practice, was limited to three cases of early syphilis and one patient with a rectal stricture following lymphogranuloma venereum. During attachment to the Royal Naval Hospital, Barrow Gurney, psychiatric homosexual patients were seen but nothing indicated that this behaviour had led them to acquire venereal disease. During early personal experience in Merseyside, not a single case was recorded until 1961. After this a small number of patients appeared and it was noticeable that they preferred to attend certain doctors and especially the clinic in Birkenhead. The total could not have exceeded 2 per cent. of all the male cases seen on Merseyside, and there was a dearth of such cases at the famous Liverpool Seamen's Dispensary.

There was one notable exception. Almost the first patient seen personally at Chester Royal Infirmary was homosexual, and he was probably the only one during $7 \frac{1}{2}$ years service there; he transferred to Birkenhead and later moved to London where he was one of the first patients whom I saw in my present department, and there he still attends. Such fidelity, extending now over 20 years, is quite touching, though by no means a record.

In 1956 Jefferiss first drew attention to the number of cases in homosexual men seen at St. Mary's Hospital, and it was apparently in 1952 that homosexual transmission was first recognised to be of increased significance. Jefferiss (1956) showed that, out of 1,000 consecutive patients with early syphilis and gonorrhoea, 8.4 per cent. admitted to infection by homosexual contact.

At St. Mary's Hospital in 1961, 81 (72 per cent.) of 113 male cases of early infectious syphilis were acquired by homosexual contact (Jefferiss, 1966). Corresponding figures for early syphilis in other London clinics were 32 per cent. at St. Thomas' Hospital (Nicol, 1960), 14 per cent. at the London Hospital (King, 1962), and 79 per cent. at St. Paul's Hospital (Mascall, 1961). Jefferiss (1966) also 
showed that, in the first 3 months of 1965, out of a total of 1,997 new male cases, 281 (14 per cent.) admitted homosexual contact. These included 31 (62 per cent.) of fifty cases of early syphilis, and 89 (15 per cent.) of 604 cases of gonorrhoea. The findings at Charing Cross Hospital from 1962 to early 1965 were published in the same year (Fluker 1966), and it is now proposed to supplement those figures to complete the 10-year period starting in 1962 and ending in 1971. For these years the data were recorded personally, but this was not possible after the end of 1971 and a few figures from computerbased data from 1972 to 1974 will be reported separately. They are less comprehensive than those for the 10 years of the Survey though they illustrate certain trends that have developed, and these are reflected in Tables VI, VIII, and IX.

\section{Consideration of the Tables}

The most notable features of Table I are first the explosive increase in the case load, particularly between 1968 and 1971 when it more than doubled, and greatly strained the resources of the department; secondly, the improved ratio of male to female casesfrom approximately $4: 1$ in 1962 to $1.5: 1$. in 1971 or, allowing for the homosexual component, approximately 1.3:1; thirdly, the increased proportion of homosexuals from 1968 to 1971 , averaging $16 \cdot 1$ per cent. over the 4 years. It might be argued that the legalizing of homosexual relations between consenting adults in 1968 was responsible. The Act may indeed have been a minor contributory factor but other clinics had returned high figures at the beginning of the decade when the atmosphere for homosexuals at the Charing Cross Hospital (West London) was decidedly unfavourable and where the upward trend started in 1963 following a deliberate medical management decision.

In Table II, homosexual infections are divided into active and passive according to the site involved. The proportions of active and passive infections were 45.1 per cent. and 54.9 per cent. respectively, and these figures remain remarkably constant in Tables III, IV, and V. This suggests a high degree of honesty in those patients with infections related to the active role who might easily have pretended to have acquired the infection from an unknown female. It also roughly represents the proportion of preference expressed for an active as against a passive role, but as a large majority of homosexuals are versatile this is probably not important. In so far as such roles are concerned we probably tend to exaggerate the role of rectal intercourse in homosexual relations because of the importance of the rectum as a repository of infection. Schofield (1964) discussed this matter at some length. Obviously those who eschew rectal intercourse run a much smaller risk. In the United Kingdom the importance of oro-genital intercourse has been neglected until recently and the absence of any data in this series is regretted, as the practice is obviously of great importance.

TABLE I Total cases, 1962-1971

\begin{tabular}{|c|c|c|c|c|c|}
\hline \multirow[b]{2}{*}{ Year } & \multirow[b]{2}{*}{ Total } & \multirow[b]{2}{*}{ Females } & \multirow[b]{2}{*}{ Males } & \multicolumn{2}{|c|}{ Homosexual males } \\
\hline & & & & No. & Per cent. \\
\hline $\begin{array}{l}1962 \\
1963 \\
1964 \\
1965 \\
1966 \\
1967 \\
1968 \\
1969 \\
1970 \\
1971\end{array}$ & $\begin{array}{r}4,206 \\
5,358 \\
5,808 \\
6,312 \\
6,824 \\
7,624 \\
9,117 \\
11,583 \\
14,947 \\
18,898\end{array}$ & $\begin{array}{r}835 \\
1,313 \\
1,663 \\
1,867 \\
2,158 \\
2,425 \\
3,117 \\
3,938 \\
5,312 \\
7,724\end{array}$ & $\begin{array}{r}3,369 \\
4,045 \\
4,145 \\
4,445 \\
4,666 \\
5,199 \\
6,100 \\
7,645 \\
9,635 \\
11,174\end{array}$ & $\begin{array}{r}105 \\
193 \\
349 \\
420 \\
559 \\
633 \\
999 \\
1,146 \\
1,628 \\
1,773\end{array}$ & $\begin{array}{r}3 \cdot 1 \\
4 \cdot 7 \\
8 \cdot 4 \\
9 \cdot 4 \\
12 \cdot 0 \\
12 \cdot 2 \\
16 \cdot 4 \\
15 \cdot 0 \\
16.9 \\
15.9\end{array}$ \\
\hline
\end{tabular}

TABLE II Cases in homosexual males, 1962-71

\begin{tabular}{|c|c|c|c|c|c|c|}
\hline \multirow[b]{2}{*}{ Year } & \multicolumn{2}{|c|}{ Active } & \multicolumn{2}{|c|}{ Passive } & \multirow[b]{2}{*}{ Total cases } & \multirow[b]{2}{*}{ No. of patients } \\
\hline & No. & Per cent. & No. & Per cent. & & \\
\hline $\begin{array}{l}1962 \\
1963 \\
1964 \\
1965 \\
1966 \\
1967 \\
1968 \\
1969 \\
1970 \\
1971\end{array}$ & $\begin{array}{r}34 \\
33 \\
168 \\
158 \\
231 \\
292 \\
447 \\
549 \\
780 \\
819\end{array}$ & $\begin{array}{l}32 \cdot 4 \\
17 \cdot 2 \\
48 \cdot 1 \\
37 \cdot 6 \\
41 \cdot 3 \\
46 \cdot 1 \\
44 \cdot 8 \\
47 \cdot 9 \\
47 \cdot 9 \\
45 \cdot 6\end{array}$ & $\begin{array}{r}71 \\
159 \\
181 \\
262 \\
328 \\
341 \\
552 \\
597 \\
848 \\
954\end{array}$ & $\begin{array}{l}67 \cdot 6 \\
82 \cdot 8 \\
51 \cdot 9 \\
62 \cdot 4 \\
58 \cdot 7 \\
53 \cdot 9 \\
55 \cdot 2 \\
52 \cdot 1 \\
52 \cdot 1 \\
54 \cdot 4\end{array}$ & $\begin{array}{r}105 \\
192 \\
349 \\
420 \\
559 \\
633 \\
999 \\
1,146 \\
1,628 \\
1,773\end{array}$ & $\begin{array}{r}100 \\
180 \\
320 \\
355 \\
402 \\
452 \\
827 \\
943 \\
1,084 \\
1,289\end{array}$ \\
\hline Mean & & $45 \cdot 1$ & & 54.9 & & \\
\hline
\end{tabular}


TABLE III Early syphilis, 1962-71

\begin{tabular}{|c|c|c|c|c|c|c|c|}
\hline \multirow[b]{3}{*}{ Year } & \multirow[b]{3}{*}{ Total } & \multirow[b]{3}{*}{ Females } & \multirow[b]{3}{*}{ Males } & \multicolumn{4}{|c|}{ Homosexual males } \\
\hline & & & & \multirow[b]{2}{*}{ Active } & \multirow[b]{2}{*}{ Passive } & \multicolumn{2}{|c|}{ Total cases } \\
\hline & & & & & & No. & Per cent. \\
\hline $\begin{array}{l}1962 \\
1963 \\
1964 \\
1965 \\
1966 \\
1967 \\
1968 \\
1969 \\
1970 \\
1971\end{array}$ & $\begin{array}{r}45 \\
65 \\
100 \\
127 \\
115 \\
101 \\
132 \\
108 \\
130 \\
138\end{array}$ & $\begin{array}{c}\text { Nil } \\
2 \\
8 \\
20 \\
16 \\
11 \\
15 \\
12 \\
13 \\
22\end{array}$ & $\begin{array}{r}45 \\
63 \\
92 \\
107 \\
99 \\
90 \\
117 \\
96 \\
117 \\
116\end{array}$ & $\begin{array}{r}1 \\
3 \\
10 \\
23 \\
21 \\
28 \\
60 \\
37 \\
54 \\
36\end{array}$ & $\begin{array}{r}4 \\
9 \\
25 \\
35 \\
34 \\
28 \\
40 \\
38 \\
41 \\
62\end{array}$ & $\begin{array}{r}5 \\
12 \\
35 \\
58 \\
55 \\
56 \\
100 \\
75 \\
95 \\
98\end{array}$ & $\begin{array}{l}11 \cdot 1 \\
18 \cdot 5 \\
38 \cdot 0 \\
54 \cdot 2 \\
55 \cdot 6 \\
62 \cdot 2 \\
85 \cdot 5 \\
78 \cdot 1 \\
81 \cdot 2 \\
84 \cdot 5\end{array}$ \\
\hline \multicolumn{3}{|c|}{ Mean per cent. } & & $45 \cdot 5$ & 54.5 & & \\
\hline
\end{tabular}

TABLE IV Gonorrhoea, 1962-71

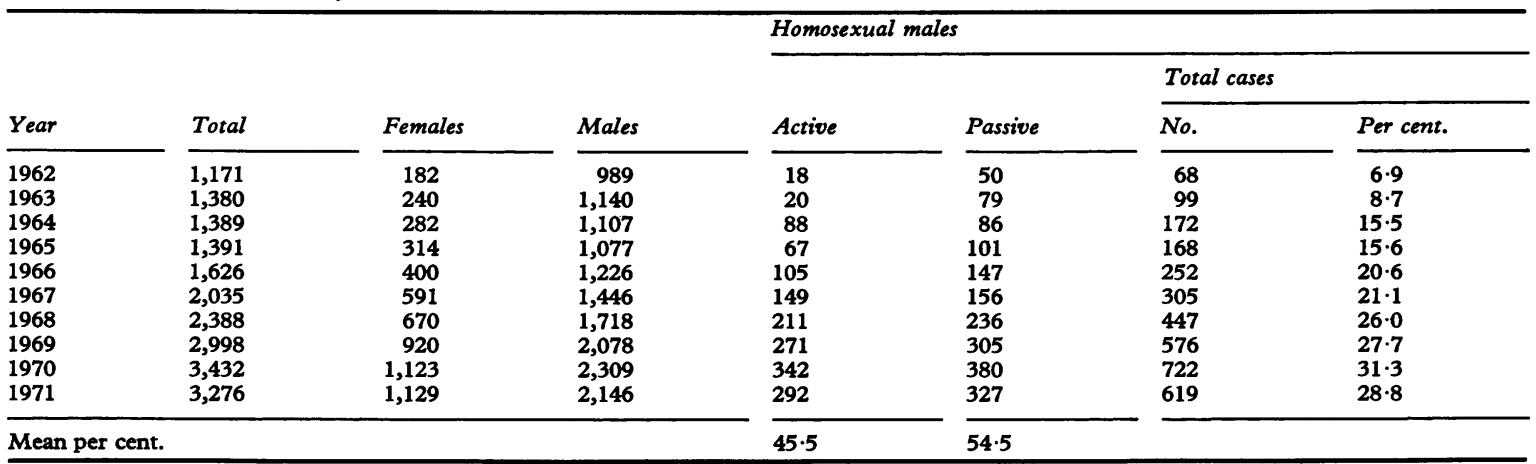

TABLE V Other sexually transmitted diseases, 1962-71

\begin{tabular}{|c|c|c|c|c|c|}
\hline \multirow[b]{3}{*}{ Year } & \multirow[b]{3}{*}{ Total } & \multicolumn{4}{|c|}{ Homosexual males } \\
\hline & & \multirow[b]{2}{*}{ Active } & \multirow[b]{2}{*}{ Passive } & \multicolumn{2}{|c|}{ Total cases } \\
\hline & & & & No. & Per cent. \\
\hline $\begin{array}{l}1962 \\
1963 \\
1964 \\
1965 \\
1966 \\
1967 \\
1968 \\
1969 \\
1970 \\
1971\end{array}$ & $\begin{array}{l}2,297 \\
2,863 \\
2,846 \\
3,204 \\
3,288 \\
3,603 \\
4,207 \\
5,427 \\
7,165 \\
8,956\end{array}$ & $\begin{array}{r}15 \\
10 \\
70 \\
68 \\
105 \\
115 \\
176 \\
241 \\
384 \\
491\end{array}$ & $\begin{array}{r}17 \\
71 \\
70 \\
126 \\
147 \\
157 \\
276 \\
254 \\
427 \\
565\end{array}$ & $\begin{array}{r}32 \\
81 \\
140 \\
194 \\
252 \\
272 \\
452 \\
495 \\
811 \\
1,056\end{array}$ & $\begin{array}{r}1.4 \\
2.8 \\
4.9 \\
6.0 \\
7.7 \\
7.6 \\
10.7 \\
9.1 \\
11.3 \\
11.8\end{array}$ \\
\hline \multicolumn{2}{|c|}{ Mean per cent. } & $44 \cdot 3$ & $55 \cdot 7$ & & \\
\hline
\end{tabular}

Table III concerns syphilis and is self-explanatory. The rate has nearly doubled since 1971, but the proportion of homosexual infections has not significantly altered. Table IV, concerning gonorrhoea, shows the relative rise in the female case load; the ratio of male:female of $1 \cdot 35: 1$, allowing for homosexuals, is similar to the findings in many other departments. Table $\mathrm{V}$ shows the increase in other sexually transmitted diseases. It is remarkable that the active/passive ratio resembles that in the previous Tables. Table VI indicates the incidence of nonspecific proctitis compared with non-specific urethritis. It is unsatisfactory because the criteria for diagnosis are as nebulous as those for non-specific genital infection in the female and largely depend on known contact with a case of non-specific urethritis and the absence of Neisseria gonorrhoeae in smears and cultures. The active/passive ratio is also out of line. One does, however, see cases of clinical proctitis which disappears after tetracycline therapy, and there seems little doubt that such a condition does exist.

Table VII is self-explanatory and reasonably accurate. The low proportion of coloured patients is supported by Table VIII, which is a computer summary of the main countries of origin. 
TABLE VI Non-specific infection, 1971, 1973, and 1974

\begin{tabular}{|c|c|c|c|c|c|}
\hline \multirow[b]{2}{*}{ Year } & \multirow[b]{2}{*}{ Total } & \multicolumn{4}{|l|}{ Homosexual males } \\
\hline & & $\begin{array}{l}\text { Active } \\
\text { (N.S. Urethritis) }\end{array}$ & $\begin{array}{l}\text { Passive } \\
\text { (N.S. Proctitis) }\end{array}$ & No. & Per cent. \\
\hline $\begin{array}{l}1971 \\
1973 \\
1974\end{array}$ & $\begin{array}{l}3,879 \\
4,588 \\
4,650\end{array}$ & $\begin{array}{l}268 \\
254 \\
256\end{array}$ & $\begin{array}{l}187 \\
275 \\
256\end{array}$ & $\begin{array}{l}455 \\
529 \\
512\end{array}$ & $\begin{array}{l}11 \cdot 4 \\
11.5 \\
11 \cdot 0\end{array}$ \\
\hline
\end{tabular}

TABLE VII Type of homosexuality, 1962-1971

\begin{tabular}{|c|c|c|}
\hline Type & No. & Per cent. \\
\hline $\begin{array}{l}\text { Exclusively homosexual } \\
\text { Bi-sexual } \\
\text { Married }\end{array}$ & $\begin{array}{r}6,520 \\
1,128 \\
156\end{array}$ & $\begin{array}{r}83 \cdot 5 \\
14 \cdot 5 \\
2 \cdot 0\end{array}$ \\
\hline $\begin{array}{l}\text { Total } \\
\text { Coloured patients }\end{array}$ & $\begin{array}{r}7,804 \\
314\end{array}$ & $\begin{array}{r}100 \cdot 0 \\
4 \cdot 0\end{array}$ \\
\hline
\end{tabular}

TABLE VIII Country of origin of all homosexual male patients, 1972-1974

\begin{tabular}{|c|c|}
\hline Country of origin & No. of cases \\
\hline $\begin{array}{l}\text { England } \\
\text { Scotland } \\
\text { Wales } \\
\text { N. Ireland }\end{array}$ & $\begin{array}{r}3,260 \\
263 \\
136 \\
137\end{array}$ \\
\hline Total United Kingdom & 3,796 \\
\hline $\begin{array}{l}\text { Eire } \\
\text { Australasia } \\
\text { U.S.A. } \\
\text { Spain } \\
\text { Mediterranean } \\
\text { S. America } \\
\text { S. Africa } \\
\text { Germany } \\
\text { France } \\
\text { Canada } \\
\text { Netherlands } \\
\text { Scandinavia } \\
\text { Switzerland } \\
\text { Russia }\end{array}$ & $\begin{array}{r}217 \\
166 \\
116 \\
105 \\
65 \\
60 \\
70 \\
57 \\
56 \\
45 \\
30 \\
23 \\
22 \\
4\end{array}$ \\
\hline Total white races & 4,832 \\
\hline $\begin{array}{l}\text { Asia } \\
\text { West Indies } \\
\text { Black Africa }\end{array}$ & $\begin{array}{r}101 \\
88 \\
135\end{array}$ \\
\hline Total coloured & $324(6.2$ per cent.) \\
\hline Total & 5,156 \\
\hline
\end{tabular}

Table IX summarizes the patients ages since the computer became available. The average for the period was 29.6 years. No figures are available but no evidence emerged that single-sex education, particularly in public schools, was a significant factor in the aetiology and/or development of homosexuality among our patients, despite a relatively high proportion from Social Classes I and II.

Table $\mathrm{X}$, which includes cases diagnosed early in 1975, shows the importance of cultures in the
TABLE IX Age groups of homosexuals, 1972-1974

\begin{tabular}{lrr}
\hline Age $(y r s)$ & \multicolumn{1}{l}{ No. } & Per cent. \\
\cline { 1 - 1 } Under 16 & 6 & $0 \cdot 2$ \\
$16-17$ & 134 & $2 \cdot 6$ \\
$18-19$ & 205 & $3 \cdot 9$ \\
$20-24$ & 1,387 & $26 \cdot 5$ \\
Over 25 & 3,496 & $66 \cdot 8$ \\
\hline
\end{tabular}

TABLE $X$ Diagnosis of rectal gonorrhoea in 137 male cases in 1975

\begin{tabular}{lcc}
\hline Test result & No. of cases & Percentage \\
\cline { 1 - 1 } \cline { 3 - 3 } Smear +ve & 63 & $46 \cdot 0$ \\
Culture +ve & 127 & $92 \cdot 7$ \\
Smear - ve & 74 & $54 \cdot 0$ \\
Culture - ve & 10 & $7 \cdot 3$ \\
\hline
\end{tabular}

diagnosis of rectal gonorrhoea in homosexual males. Our laboratory facilities, which in 1962 were so bad as to be virtually non-existent, are now first class.

Waugh (1972) published a detailed survey of the patients with syphilis seen during 1970 and 1971 at the West London Hospital ; this showed a difference in the patients' occupations as compared with those attending St. Mary's Hospital (Jefferiss, 1956). Of the cases reported by Waugh (1972), 14 per cent. came from the professional classes, whereas the majority of the patients at St. Mary's Hospital were hairdressers, waiters, clerks, shop assistants, and artistes (Jefferiss, 1956). The question arises whether some information was false, or whether there has been a genuine change. There is no doubt that many patients do give false personal details when they first attend. For example, a solicitor or even a clergyman may call himself a clerk.

\section{Serum hepatitis}

Much has recently been published about the transmission of serum hepatitis and its high incidence among homosexuals. Coleman and Waugh (1976) reported an exceptionally high incidence among our patients. I had suspected this ever since 1966 when Vahrmann (personal communication) made an original observation for the time that many of our homosexual patients who had or had had secondary syphilis werè admitted to hospital suffering from hepatitis and that he thought the condition might well be sexually transmitted. 


\section{Herpes genitalis}

Since the end of this study, we have seen a number of cases of perianal herpes simplex and in ten patients the eruption was preceded by very severe pain for about 2 days.

\section{Genital warts}

It is occasionally necessary to remind other specialists that, in the presence of genital and anal warts, other sexually transmitted diseases, particularly rectal gonorrhoea and syphilis, must be excluded.

\section{Miscellaneous conditions}

So far as other conditions peculiar to this group of patients is concerned, there were fifteen cases of ischio-rectal abscess, in four of which the condition was recurrent. There were no such cases among our heterosexual patients. A further four patients had tight anal sphincters which rendered passive intercourse almost impossible.

There were ten patients with mucous colitis. Many homosexuals have mucus in the rectum even in the absence of demonstrable infection, but in these men the accumulation was excessive and led to the passage of mucous stools. Six patients were referred to a gastroenterologist who confirmed the diagnosis. All these patients had an introspective and overanxious personality.

The number of repeated infections in the same individual is impossible to state with any accuracy but is extremely high. The record for repeated infections belongs to a patient now aged 36 who first attended in 1960 and has had no less than 48 separate episodes, but others have had twenty, thirty, or even more episodes in shorter periods. The fidelity of some patients to their clinics (in marked contrast to their sexual partners) perhaps suggests an element of consumer satisfaction. On the other hand it is well known that many patients attend all the London clinics in turn; if it were possible to verify such peregrinations the results might indeed be startling.

\section{H.M. Prisons}

During the period of the survey sessions were undertaken at Her Majesty's Prison at Wormwood Scrubs and the Ashford Remand Home, and a short note on prisoners is included. In the latter establishment the patients are short-stay and are sometimes only seen once or twice. Occasional homosexuals appear but it is impossible to draw any valid conclusions owing to this rapid turnover. The prisoners stay for longer periods at H.M. Prison, Wormwood Scrubs, and it is usual to form a stable doctor/patient relationship. In 9 years there have been five known outbreaks of gonorrhoea and one of syphilis from homosexual transmission within the prison. The patients with gonorrhoea came forward and revealed their contacts and each episode was effectively controlled without the slightest trouble. In one instance two of the patients involved were such dangerous criminals as to be considered unsafe for this particular prison and were rapidly moved on.

The syphilis episode was less happy. The first patient had been given small amounts of ampicillin and tetracycline for adenitis before being referred; this had masked the infection and there was a considerable delay before serological tests became positive. Unfortunately he was psychiatrically disturbed and indiscreet so that his contacts were afraid to come forward owing to ill-advised disciplinary action taken without my knowledge. The risk of the infection spreading was thus vastly increased, but in the end the matter was resolved.

\section{Homosexual reorientation}

In a previous paper (Fluker, 1966) it was shown that only ten patients out of 200 had any interest in receiving psychiatric treatment with a view to changing their sexual orientation, and that only six had kept an appointment with a psychiatrist, at least one of them for another psychiatric condition. It was claimed (Fluker, 1966) that one patient was permanently reorientated. About 2 years later this patient returned to the clinic complaining of severe rectal discomfort. This was caused by prolapsed haemorrhoids (requiring surgical treatment) and there was no evidence of any other trouble. He was then happily married and claimed that all his homosexual inclinations had disappeared. This is the only patient I have ever seen who experienced apparently permanent reorientation. Undoubtedly well-adjusted persons, particularly bi-sexuals who are married, may be able to control their homosexual impulses, but this does not amount to elimination of the homosexual component. Nevertheless, motivation for change in homosexuals seems very low and the number who genuinely desire reorientation appears to be infinitesimal; out of a further 500 interviewed at considerable length, only five evinced any interest in attempting such a change.

Although Wells and Schofield (1973) assert, according to the Eysenck Personality Inventory, that homosexuals as a group score lower for extroversion than heterosexual males but are significantly more neurotic than the general population, serious personality disorders do not seem to be much in evidence among our patients. Those who are exclusively homosexual seem better adjusted than bi-sexuals and, as Waugh (1972) pointed out, they readily co-operate in persuading their contacts to attend the clinic.

There are, however, two major fears harboured by some homosexuals, which I have discovered from various groups outside the clinics. One is the platinum loop, as they are terrified that it will be 
inserted right into the urethra while it is red hot, and the other problem is the contact slip. Many homosexuals still fear the police, and are therefore afraid to carry these pieces of paper. We never insist on a patient's taking a contact slip but we do ask him to tell his contacts to give the appropriate details at their first attendance. There is surprisingly satisfactory co-operation in this matter and almost all are willing to see our welfare officer with a view to facilitating contact tracing. Amongst the last 172 exclusively homosexual patients with syphilis, 102 homosexual partners were seen as a result of contact tracing with the patients' co-operation and 64 were found to be infected.

Bi-sexual men are much more difficult. Their homosexual relations are often transient, perhaps snatched in the squalor of a public convenience, and often they do not know the identity of their partner.

The most difficult patients of all are married men. Sometimes they have been living a double life, perhaps for years, and are completely unsuspected by their families when suddenly an infection occurs and is passed on to the wife. Much depends on how the physician handles the couple, as the marriage may easily be wrecked, but this catastrophe may be avoided and the patient may be enabled to come to terms with his double life without further help if he is a well-adjusted person. Sometimes the stress is too much and severe strain occurs resulting in an anxiety state, severe depression, or both; in these circumstances psychiatric help will be required. It should be remembered how difficult it must be for a young man who thinks that he has a sexually transmitted disease to come and tell a complete stranger in a clinic, and the difficulty is enormously compounded if he has to confess to being homosexual as well. But consider the position of a young wife with a family, who thinks that she is happy and secure in her husband's love and suddenly discovers that he is homosexual and that he has also infected her with gonorrhoea. For the ordinary person such a position is quite unthinkable and yet it does happen and if they have to come to the clinic these people deserve all the consideration and guidance that can be given.
Some marriages can be retrieved but sometimes this neither possible nor wise in the interests of both parties.

\section{Conclusion}

Although a considerably higher incidence of homosexual infection has probably always existed than was once realized, there seems little doubt that there has been a great increase in recent years as with heterosexual infection. On the other hand, the situation at Charing Cross Hospital is not typical of the country as a whole and it does not provide any evidence for saying that the homosexual population is increasing as a proportion of the whole. These patients will come to certain clinics in the largest cities. Ease of access with good transport facilities is a major factor but above all the attitude of the clinic staff is crucial. The flood of homosexual patients which has been maintained in full flow since 1966 stemmed from a personal decision to provide as humane and efficient a service as possible for them. They like to have their favourite physician when they come and this personal element is essential for success. The rapid growth of the department with ever more patients and staff makes this personal element much more difficult to sustain, especially with the inevitable changes in junior staff, and consultant involvement is essential to provide the necessary continuity.

\section{References}

Coleman, J., and Waugh, M. A. (1976) In press FLUKER,'J. L. (1966) Brit. F. vener. Dis., 42, 48

Harkness, A. H. (1948) Proc. roy. Soc. Med., 41, 476

JEFFERISS, F. J. G. (1956) Brit. F. vener. Dis., 32, 17 (1966) Ibid., 42, 46

King, A. J. (1962) Proc. roy. Soc. Med., 55, 869

MASCALL, N. (1961) Brit. med. F., 1, 899

Nicol, C. S. (1960) Practitioner, 184, 345

SchofizLd, M. (1964) Brit. F. vener. Dis., 40, 129

VAHRMANN, T. (1966) Personal communication

WaUGH, M. A. (1972) Brit. f. vener. Dis., 48, 534

Welis, B. W. P., and SChOFIELD, C. B. S. (1972) Ibid., 48, 75 